CZASOPISMO INŻYNIERII LĄDOWEJ, ŚRODOWISKA I ARCHITEKTURY

JOURNAL OF CIVIL ENGINEERING, ENVIRONMENT AND ARCHITECTURE

JCEEA, t. XXXIV, z. 64 (3/II/17), lipiec-wrzesień 2017, s. 161-180, DOI:10.7862/rb.2017.162

\author{
Dominika KUŚNIERZ-KRUPA ${ }^{1}$ \\ Michał KRUPA ${ }^{2}$
}

\title{
HEPPENHEIM JAKO MODELOWY PRZYKŁAD DOBRZE WYKORZYSTANEGO POTENCJAŁU KULTUROWEGO MAŁEGO MIASTA
}

\begin{abstract}
Heppenheim położone jest w Hesji na terenie zachodnich Niemiec. Jest to niewielki ośrodek, który obecnie liczy 25 tysięcy mieszkańców. Miasto ma jednak bogatą i barwną historię oraz cenny zasób kulturowy, który jest odpowiednio chroniony, a przede wszystkim właściwie eksponowany i wykorzystany. Prawa miejskie Heppenheim otrzymało na początku XIV wieku, ale ośrodek powstał znacznie wcześniej. Pierwsza wzmianka o jego istnieniu pochodzi już z wieku VIII. W mieście znajduje się m.in. średniowieczny, pięcioboczny rynek z odrestaurowanymi, XVII-wiecznymi szachulcowymi domami, barokowy ratusz, kościół parafialny pw. św. Piotra, XIII-wieczny zamek Starkenburg, budynek sądu Elektoratu Moguncji z XIV wieku oraz niezliczona rzesza XVI, XVII i XVIII-wiecznych domów, charakterystycznych dla małomiasteczkowej architektury niemieckiej, wzniesionych wzdłuż wąskich, malowniczych ulic historycznego centrum miasta. Ze względu na perfekcyjnie przeprowadzoną rewaloryzacje, udostępnienie i upowszechnienie zabytkowych obiektów i przestrzeni mieszkańcom oraz przyjezdnym Heppenheim może stanowić cenny wzór dla innych miast zabytkowych. Obecnie, wiele małych ośrodków na terenie Polski, które mogą poszczycić się cennym zasobem kulturowym boryka się z problemami gospodarczymi i brakiem miejsc pracy, co w konsekwencji prowadzi do zastoju i braku perspektyw na dalszy rozwój. Sposobem na progres gospodarczy oraz rozkwit takich miast może być turystyka kulturowa, tak dobrze rozwinięta $w$ miastach niemieckich, czego przykładem jest właśnie Heppenheim.
\end{abstract}

Słowa kluczowe: Heppenheim, krajobraz kulturowy, miasto zabytkowe, rewaloryzacja

\footnotetext{
${ }^{1}$ Autor do korespondencji/corresponding author: Dominika Kuśnierz-Krupa, Politechnika Krakowska, Wydział Architektury, ul. Podchorążych 1, 30-084 Kraków; tel.: 12628 2429; e-mail: dkusnierz-krupa@pk.edu.pl

${ }^{2}$ Michał Krupa, Politechnika Rzeszowska, Zakład Urbanistyki i Architektury, al. Powstańców Warszawy 12,35-959 Rzeszów; tel.: 17865 1691; e-mail: mkrupa@prz.edu.pl
} 


\section{Wprowadzenie}

Miasto Heppenheim położone jest w Hesji, na terenie Niemiec. Jest to niewielki ośrodek, który obecnie liczy 25 tysięcy mieszkańców. Ma jednak bogatą i barwną historię oraz cenny zasób kulturowy, który jest odpowiednio chroniony, a przede wszystkim właściwie eksponowany i wykorzystany. Dzięki perfekcyjnie przeprowadzonej rewaloryzacji, udostępnieniu i upowszechnieniu zabytkowych obiektów i przestrzeni mieszkańcom oraz przyjezdnym Heppenheim może stanowić cenny wzór dla innych miast zabytkowych (rys. 1-2).

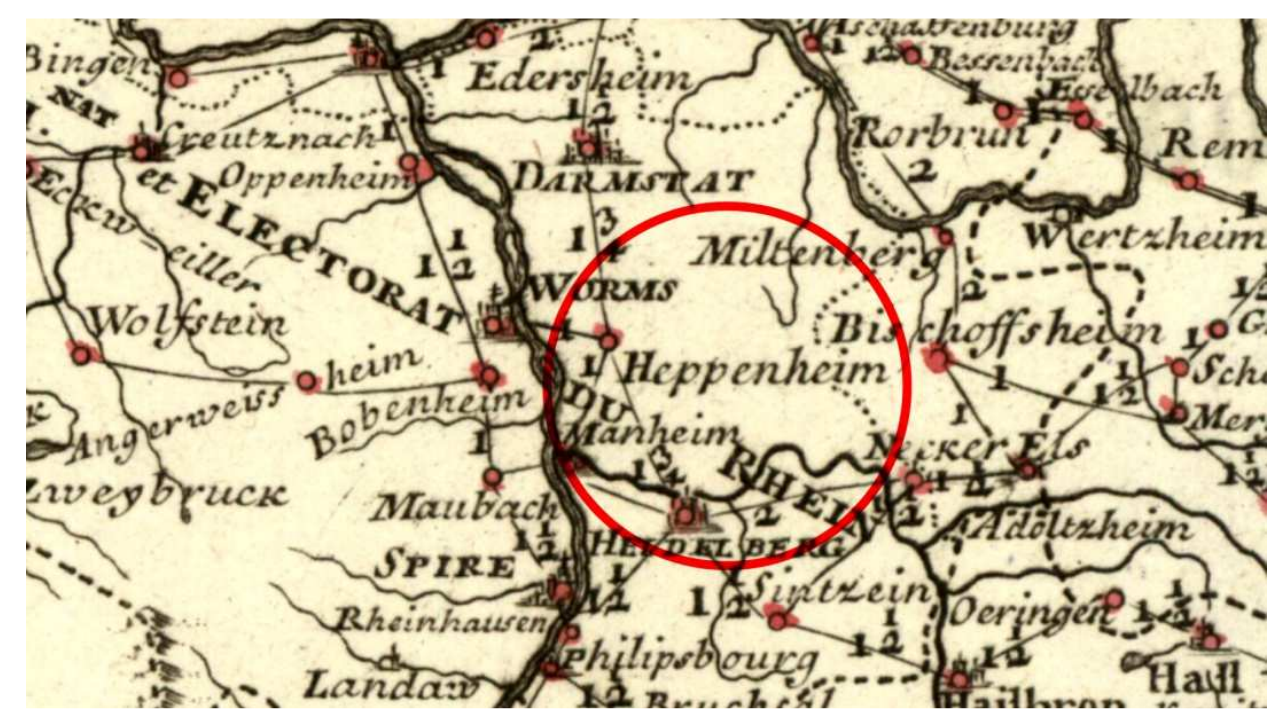

Rys. 1. Fragment mapy Niemiec z lat 1632-1712 (autor: A.- H. Jaillot), na której oznaczono Heppenheim. Kopia mapy [w:] Archiwum Katedry Historii Architektury, Urbanistyki i Sztuki Powszechnej Wydziału Architektury Politechniki Krakowskiej, s.v.

Fig. 1. Fragment of the map of Germany from the years 1632-1712 (author: A.- H. Jaillot), in which Heppenheim was marked. Copy of the map [in:] Ar-chive of the Chair of History of Architecture, Urban Planning and Art, Faculty of Architecture, Cracow University of Technology, s.v.

\section{Z historii miasta}

Pierwszy raz w dokumentach źródłowych Heppenheim wymieniono w VIII wieku, w akcie darowizny wydanym przez Machariusa z Weinheim. Niedługo później Heppenheim na mocy nadania Karola Wielkiego weszło w skład uposażenia opactwa Lorsch i przez kolejne wieki było pod panowaniem klasztoru [10]. 


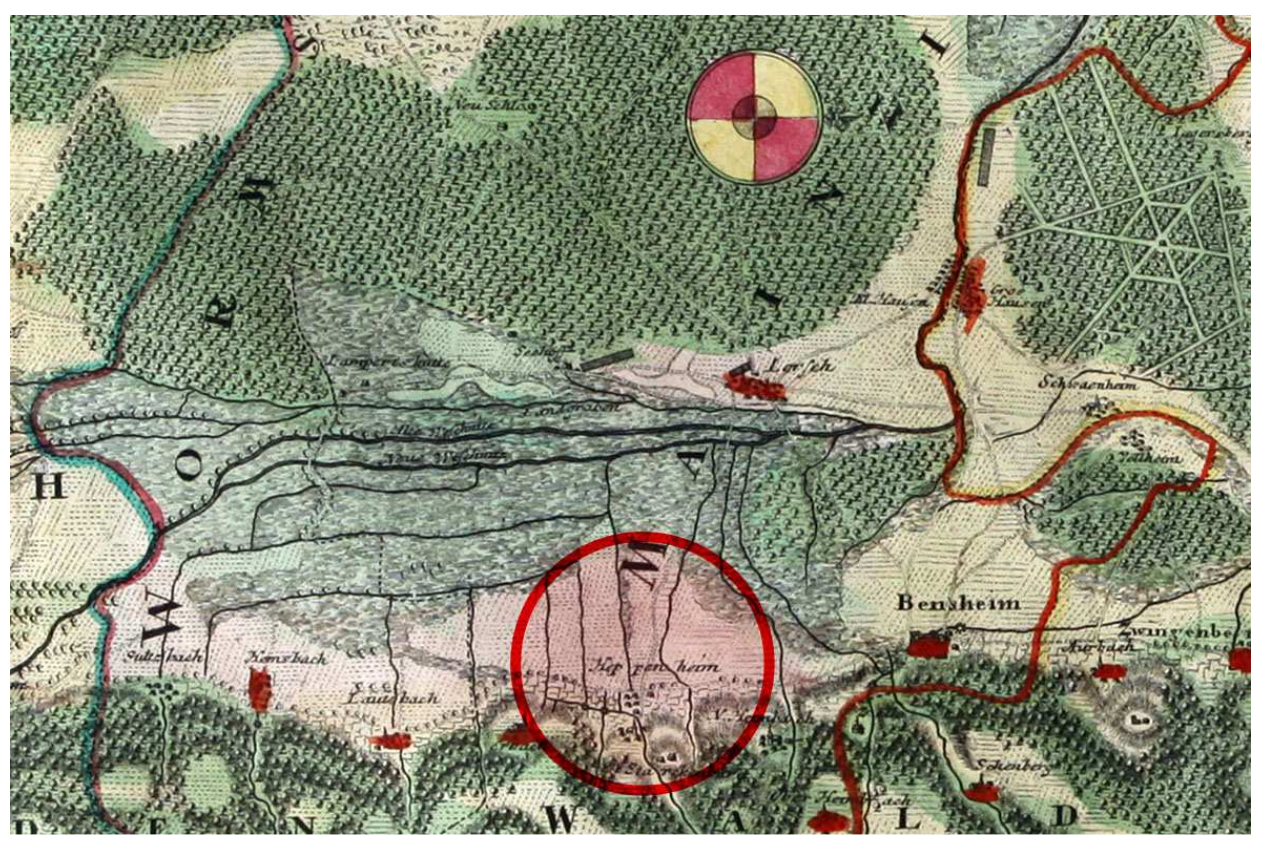

Rys.2. Fragment mapy Niemiec z lat 1632-1712 (autor: A.- H. Jaillot), na której oznaczono Heppenheim. Kopia mapy [w:] Archiwum Katedry Historii Architektury, Urbanistyki i Sztuki Powszechnej Wydziału Architektury Politechniki Krakowskiej, s.v.

Fig. 2. Fragment of the map of Germany from the years 1632-1712 (author: A.- H. Jaillot), in which Heppenheim was marked. Copy of the map [in:] Ar-chive of the Chair of History of Architecture, Urban Planning and Art, Faculty of Architecture, Cracow University of Technology, s.v.

W 1065 roku ówczesny opat Lorsch - Udalrich nakazał budowę obronnego zamku na wzgórzu w Heppenheim. Zamek, zwany Starkenburg miał był punktem oporu wobec Arcybiskupa Adalberta z Bremy, który chciał, aby opactwo Lorsch znalazło się pod jego rządami. W 1232 roku zarówno Heppenheim z zamkiem Starkenburg, jak również Opactwo Lorsch weszły w skład dóbr Arcybiskupstwa Moguncji. Zamek nadal pełnił funkcję obronną. Służył również jako administracyjne centrum regionu „Amt Starkenburg”. W zamku aż do XVII wieku rezydowali także burgrabiowie, najwyżsi urzędnicy arcybiskupa, którzy w latach byli również najwyższej rangi urzędnikami Elektoratu Palatynatu. W imieniu władcy podejmowali oni decyzje w zakresie administracji, wyższego sądownictwa i obrony terytorialnej [4].

Prawa miejskie Heppenheim otrzymało na początku XIV wieku, ale nie rozwinęło się w większe miasto. Do wieku XIX pozostało niewielkim ośrodkiem z charakterystyczną dla miast niemieckich zabudową szachulcową. Mieszkańcy Heppenheim trudnili się rzemiosłem, zorganizowanym w stowarzyszenia kupieckie - gildie, rolnictwem oraz uprawą winorośli [9]. 
W 1803 roku na mocy dekretu Cesarskiej Deputacji Elektorat Moguncji został zniesiony, w związku z czym Heppenheim stało się częścią Landgrafostwa, a od 1806 roku Wielkiego Księstwa.

Proces industrializacji, rozwijającej się w Europie w XIX wieku docierał do Heppenheim stopniowo, co wpłynęło na fakt, że miasto zachowało swój rzemieślniczo-rolniczy charakter(rys.4). W 1846 roku przez ośrodek poprowadzono linię kolejową Main - Neckar. Ta inwestycja jak, również to, że miasto od 1832 roku było centrum regionu administracyjnego i w trakcie epoki imperialnej odnosiło korzyści z rozwoju sektora publicznego i poprawy infrastruktury komunalnej, sprawiły, że z czasem w Heppenheim wzrosła liczba mieszkańców (z 4500 do ponad 7000), a teren miasta się powiększył. Pomiędzy 1880 a 1914 rokiem w Heppenheim wybudowano nowe obiekty użyteczności publicznej, w tym administracyjne oraz oświatowe, a na obrzeżach historycznego centrum powstała luksusowa dzielnica mieszkaniowa. Rozwój miasta przerwał wybuch I wojny światowej [1] (rys. 3-4).

Podczas lat kryzysu w okresie Republiki Weimarskiej, Heppenheim rozwijało się bardzo powoli. Miasto doświadczyło też ponurego okresu dyktatury nazistów podczas II wojny światowej, której nie przeżyła żydowska część jego społeczności.

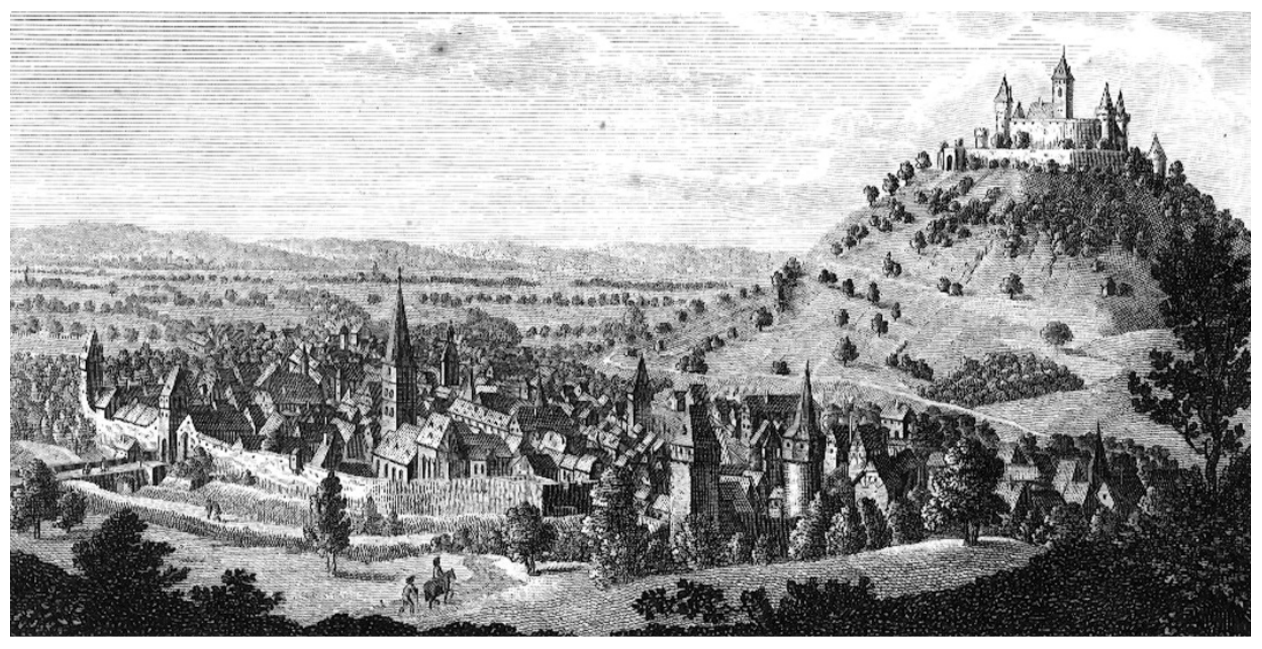

Rys. 3. Heppenheim na sztychu Mateusza Meriana z 1 połowy XVII wieku. Kopia w archiwum Katedry Historii Architektury, Urbanistyki i Sztuki Powszechnej Wydziału Architektury Politechniki Krakowskiej, s.v.

Fig. 3. Heppenheim on the sketch by Matthew Merian from the 1st half of the 17th century. Copy in the Archive of the Chair of History of Architecture, Urban Planning and Art, Faculty of Architecture, Cracow University of Technology, s.v. 


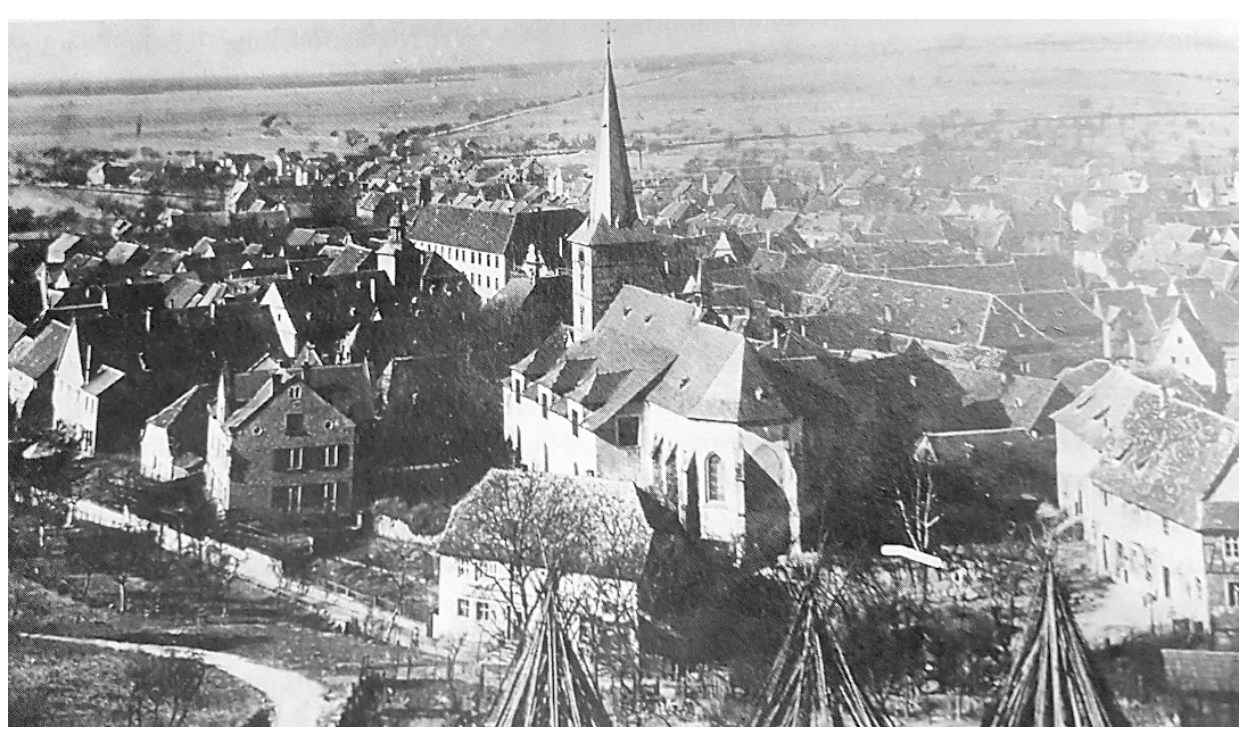

Rys. 4. Heppenheim na końcu XIX wieku. Kopia zdjęcia [w:] Archiwum Autorów

Fig. 4. Heppenheim at the end of the 19th century. Copy of the photo [in:] the Authors' Archive

Dopiero w latach 50-tych XX wieku Heppenheim zaczęło ponownie rozwijać się po latach zastoju związanego z I i II wojną światową. W mieście zaczęto wznosić nowe budynki. Na zachód od historycznego centrum zaczęła formować się nowa dzielnica mieszkaniowa, w której z czasem zaczęły postawać także niewielkie obiekty przemysłowe [10].

W wyniku reformy samorządowej, przeprowadzonej w 1972 roku, Erbach, Hambach, Igelsbach, Kirschhausen, Mittershausen-Scheuerberg, OberLaudenbach, Sonderbach i Wald-Erlenbach stały się dzielnicami Heppenheim. Obecnie miasto liczy około 25 tysięcy mieszkańców i jest siedzibą powiatu.

\section{Dziedzictwo kulturowe miasta}

Heppenheim do dzisiaj może poszczycić się pokaźnym zasobem zabytków dziedzictwa kulturowego. Jego rewaloryzacja, a następnie odpowiednie wyeksponowanie i utrzymanie stało się jednym z największych wyzwań dla władz miasta i jego społeczności.

Struktura urbanistyczna Heppenheim jest charakterystyczna dla europejskich wczesnośredniowiecznych ośrodków miejskich. Jest mało regularna i jedynie zdradza dążenie do układu zdefiniowanego, który jako kanon wykształcił się na terenie Europy Zachodniej w wieku XIII. Sylwetę miasta oraz jego charakter z 1 połowy XVII wieku dobrze oddaje sztych Mateusza Meriana (rys. 3.). 
Przedstawiony na nim Heppenheim to miasto $\mathrm{z}$ rozbudowanym systemem obronnym w postaci zapewne średniowiecznych murów obronnych z szeregiem baszt i wież (rys. 5.). Do miasta według przykazów prowadziły trzy bramy. W sylwecie Heppenheim dominuje strzelista wieża gotyckiego kościoła parafialnego oraz w jego tle mniejsza wieża ratusza. Nad miastem góruje potężny zespół zamkowy Starkenburg.

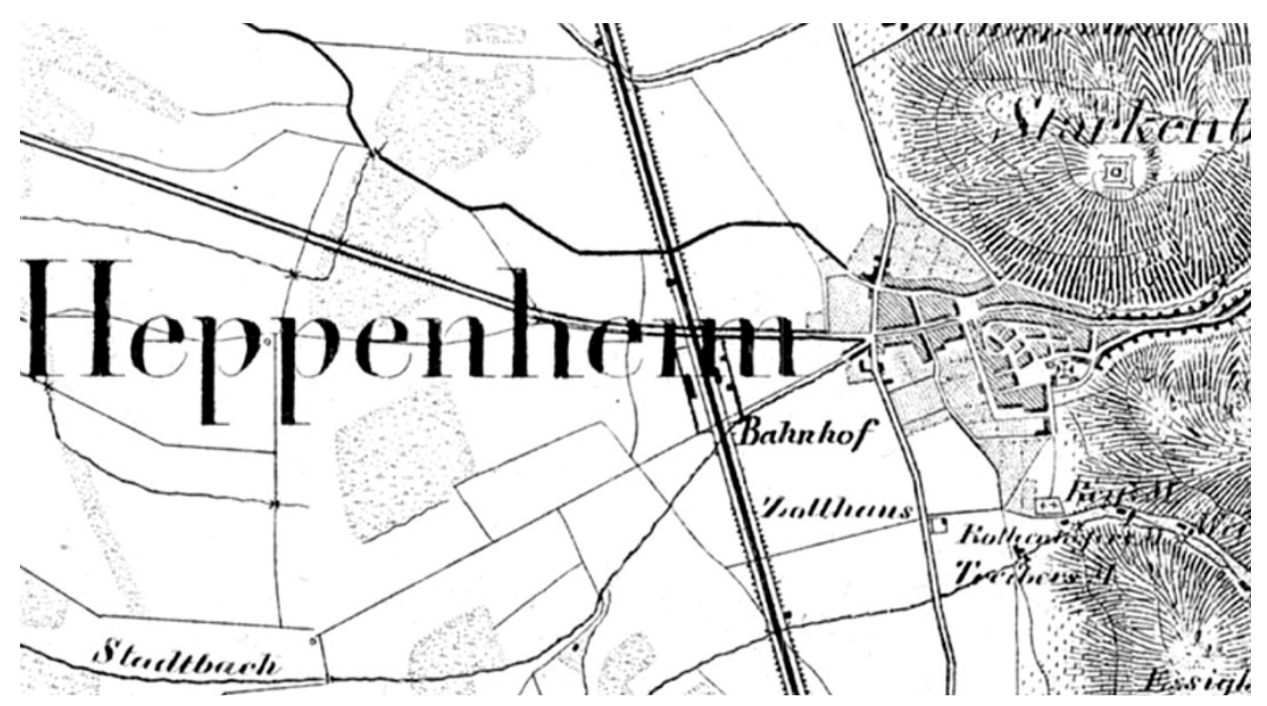

Rys. 5. Fragment sekcji 26 archiwalnej mapy Hesji z lat 1823-1850, na której zaznaczono historyczny układ urbanistyczny miasta Heppenheim. Kopia mapy [w:] Archiwum Katedry Historii Architektury, Urbanistyki i Sztuki Powszechnej Wydziału Architektury Politechniki Krakowskiej, s.v.

Fig. 5. Fragment of section 26 of the archive map of Hessen from the years 1823 - 1850, on which the historic urban layout of the town of Heppenheim was marked. Digital map [in:] Archive of the Chair of History of Archi-tecture, Urban Planning and Art, Faculty of Architecture, Cracow University of Technology, s.v.

W centrum miasta znajduje się niewielki rynek, o kształcie pięcioboku, z którego wychodzi łącznie osiem ulic: Kellerei-, Schul-, Markt-, Amts-, Muehl, Schunken-, Kirchengasse i Laudenbacher Tor . Przestrzeń tę zamykają dwui trzypiętrowe domy wzniesione w konstrukcji szachulcowej na końcu XVII wieku, na fundamentach wcześniejszych, które spłonęły w pożarze w 1693 roku. W przeszłości rynek zwany był przez mieszkańców wielkim targiem, na którym kupowano i sprzedawano towary. Należała do niego także otwarta hala ratusza, zlokalizowanego $\mathrm{w}$ jego wschodniej pierzei. Na środku rynku położona jest XVIII-wieczna fontanna z figurą Dziewicy Maryi [5] (rys. 6-9). 


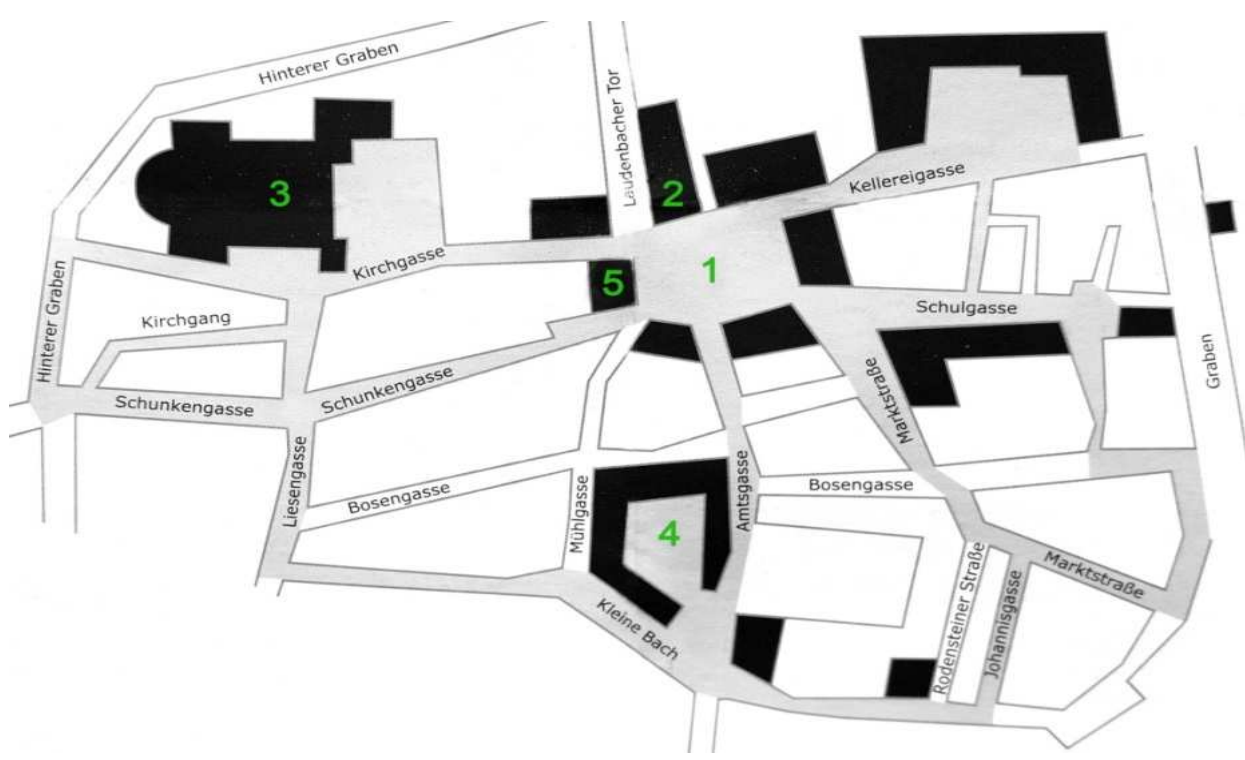

Rys. 6. Plan centrum Heppenheim z oznaczeniem opisywanych w tekście przestrzeni i obiektów. Legenda: 1 - rynek; 2 - ratusz; 3 - kościół pw. Św. Pawła; 4 - sąd Elektoratu Moguncji; 5 - informacja turystyczna. Mapa oprac. przez Autorów na podstawie planu Heppenheim, Wyd. Urząd Miasta 2015

Fig. 6. Plan of the centre of Heppenheim with marked spaces and objects de-scribed in the text. Legend: 1 - main square; 2 - town hall; 3 - St. Paul's church; 4 - courthouse of the Mainz Electorate; 5 - tourist infor-mation. Map prepared by Authors based on the plan of Heppenheim, publ. Town Council 2015

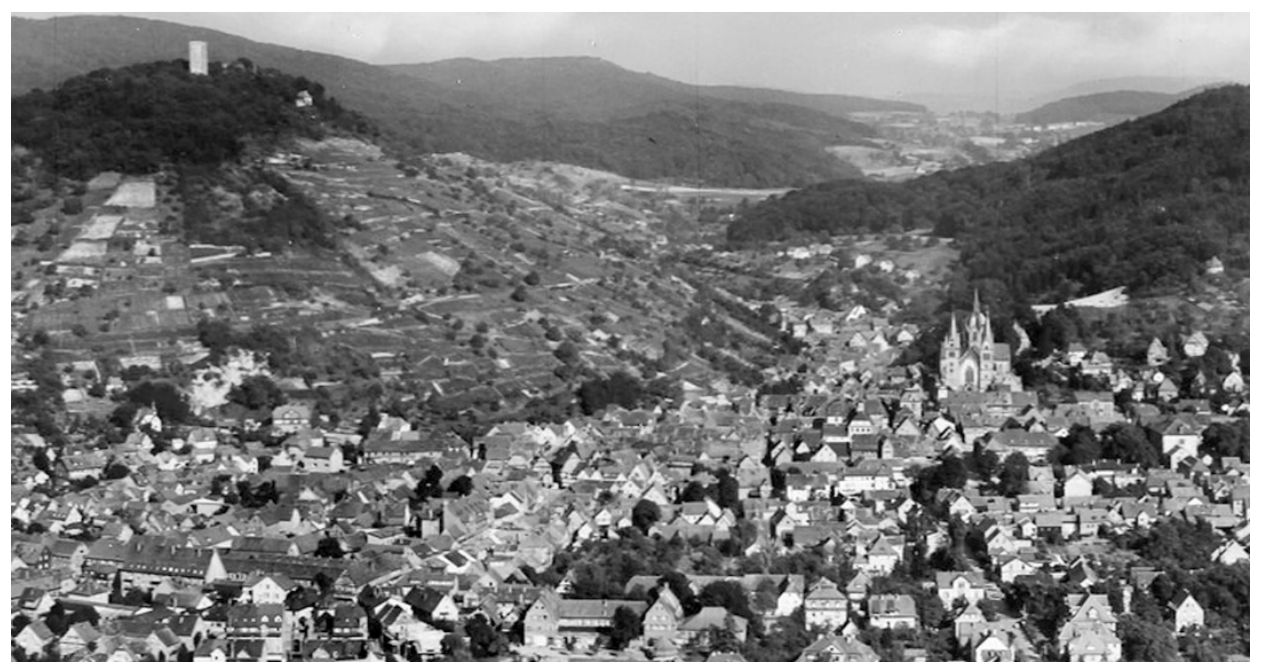

Rys.7. Heppenheim na początku XX wieku. Kopia zdjęcia [w:] Archiwum Autorów

Fig. 7. Heppenheim at the first part of the 20th century. Copy of the photo [in:] the Authors' Archive 
Podsumowując, należy stwierdzić, że średniowieczny rynek w Heppenheim posiada wysokie wartości kulturowe przede wszystkim ze względu na swoją spójność architektoniczną (rys. 8-9.)

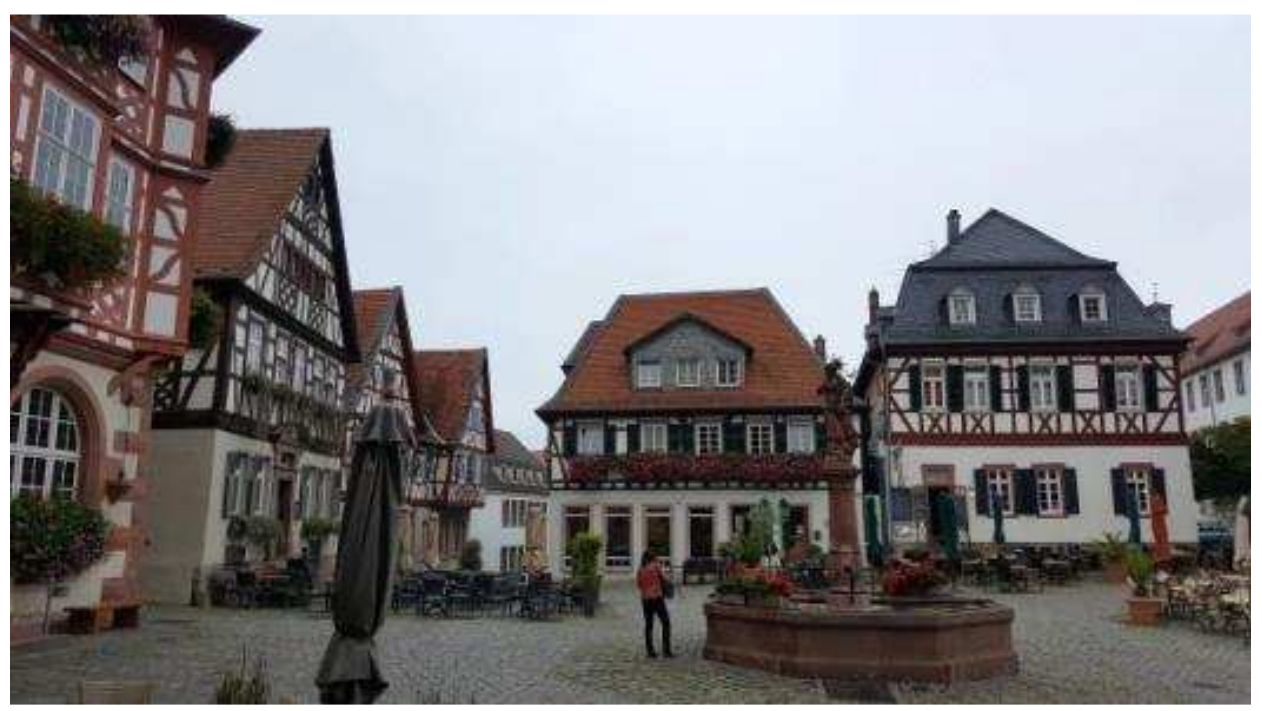

Rys. 8. Rynek w Heppenheim obecnie. Widok na pierzeję zachodnią. Fot. Autorzy, 2016

Fig. 8. Main Square in Heppenheim nowadays. View of the western frontage. Photo: Authors, 2016

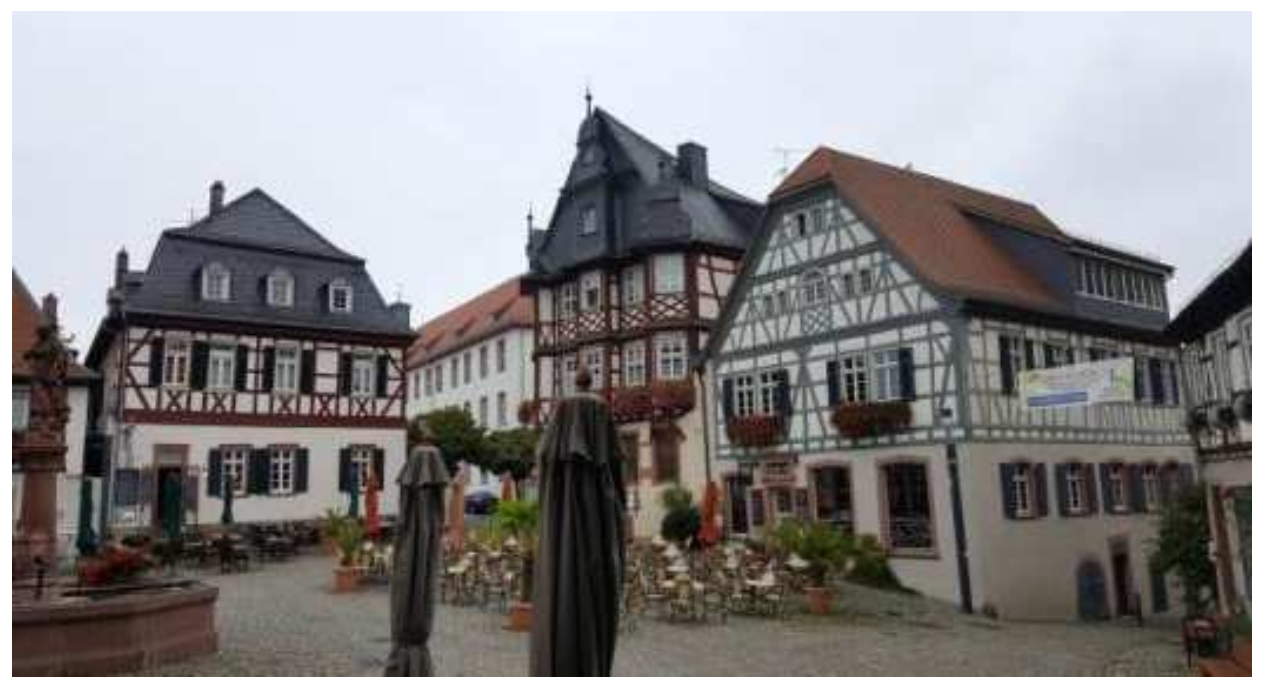

Rys. 9. Rynek w Heppenheim obecnie. Widok na północno-zachodni narożnik. Fot. Autorzy, 2016 Fig. 9. Fig. 9. Main Square in Heppenheim nowadays. View of the north-west corner. Photo: Authors, 2016 
Przy rynku położony jest, wymieniony już wcześniej, barokowy ratusz o półszkieletowej konstrukcji. Pierwszy budynek ratusza stał tutaj już w połowie XV wieku. Kolejny zbudowano około 100 lat później. Ten strawił pożar jaki wybuchł w mieście na końcu XVII wieku. Do dzisiaj z jego konstrukcji zachował się jedynie parter wzniesiony z kamienia. Ratusz odbudowano na początku XVIII wieku, a w 1929 roku dobudowano doń, od strony południowej nowy aneks. Około 30 lat później podczas remontu w wyniku zaniedbania spłonęła więźba dachowa wraz z zabytkową wieżą. Wkrótce potem została ona odbudowana, dzięki staraniom mieszkańców miasta (rys. 10-11).

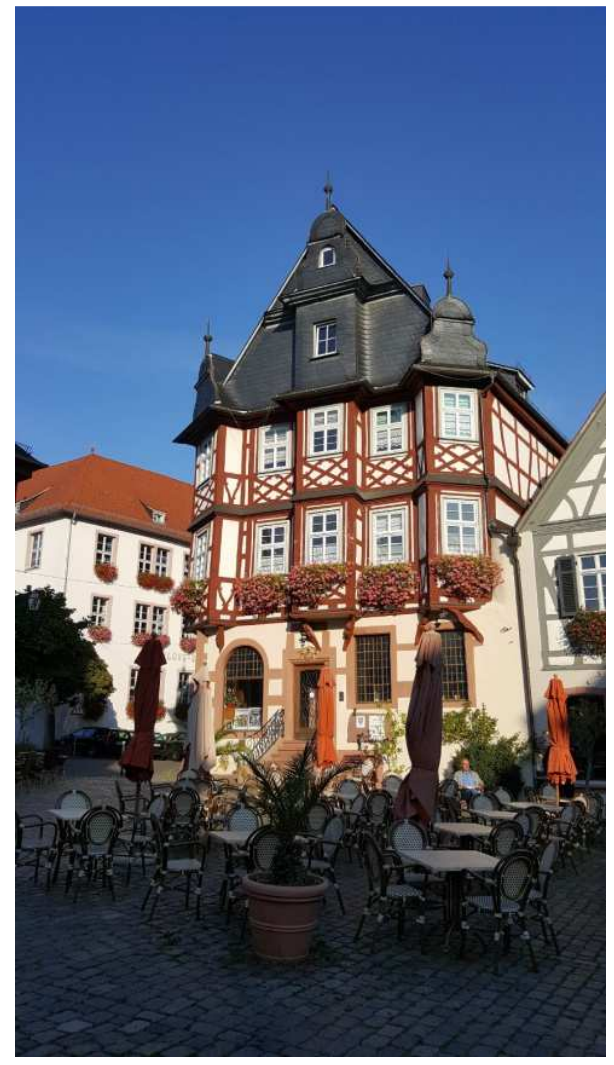

Rys. 10. Zabytkowy ratusz w Heppenheim obecnie. Widok od strony rynku. Fot. Autorzy, 2016

Fig. 10. Historic town hall in Heppenheim nowadays. View from the market square. Photo: Authors, 2016

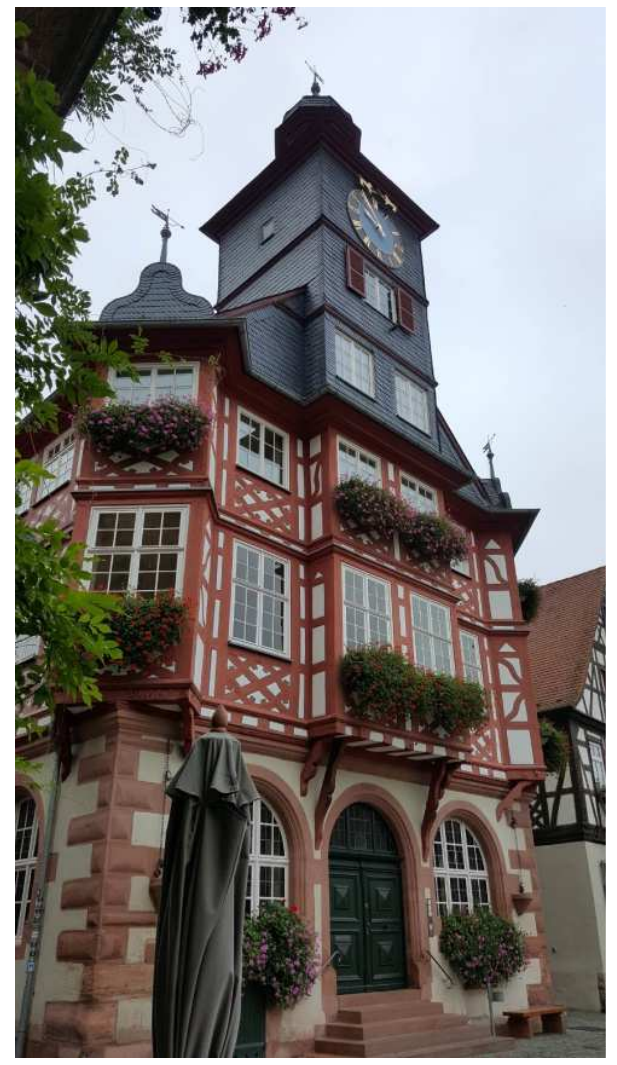

Rys. 11. Zabytkowy ratusz w Heppenheim obecnie. Widok od strony Schunkengasse. Fot. Autorzy, 2016

Fig. 11. Historic town hall in Heppenheim nowadays. View from Schunkengasse. Photo: Authors, 2016 
W kondygnacji parteru ratusza, na jego elewacji frontowej wzrok przekłuwają łukowato zwieńczone dwa otwory okienne, pośrodku których zlokalizowane jest reprezentacyjne wejście do obiektu. Kondygnacje wyższe - pierwsze i drugie piętro wzniesiono w konstrukcji szachulcowej. Zdobią je dwukondygnacyjne wykusze. Całość elewacji frontowej wieńczy drewniana wieża z zegarem [10].

Budynek znajduje się w znakomitym stanie technicznym. Jest wizytówką Heppenheim i jego największą ozdobą. Uważa się, że to jeden z najpiękniejszych, wzniesionych w konstrukcji szachulcowej ratuszy w Niemczach.

Kolejnym, ważnym dla krajobrazu kulturowego miasta obiektem, który stanowi o jego tożsamości kulturowej jest katolicki kościół parafialny pw. św. Piotra, nazywany również Katedrą Bergstrasse (rys. 12). Wzniesiono go na przełomie 1900 i 1904 roku, w miejscu wcześniejszych świątyń, z których najstarsza datowana jest na połowę VIII wieku. W źródłach określono ją jako basilica, co oznacza, że była kościołem parafialnym dla całej okolicy. W 773 roku Karol Wielki nadał Heppenheim wraz z kościołem opactwu benedyktynów w Lorsch [7]. Kiedy na początku 2 połowy XIII wieku nastał kres niezależności opactwa, ówczesny arcybiskup Moguncji Zygfryd III podarował w 1266 roku Heppenheim (rok później także kościół) kapitule katedralnej w Moguncji. Z pierwotnego obiektu do naszych czasów nie przetrwały żadne relikty. Prawdopodobnie jego pozostałości wykorzystano przy budowie kolejnych świątyń. Można domniemywać, że średniowieczny kościół sprzed przebudowy, która miała miejsce na przełomie XVII i XVIII wieku został uwieczniony na sztychu Meriana z połowy XVII wieku. Wspomniana przebudowa (z lat 1698-1700) związana była z faktem, że wcześniejsza świątynia była już zbyt mała dla stale powiększającej się parafii, a także ze zniszczeniami obiektu podczas wojny dziewięcioletniej (inaczej wojna o Palatynat, 1688-1697). Z wcześniejszego kościoła zachowano wieżę i chór, do których dobudowano nową nawę (dłuższą od poprzedniej). Nawy boczne otrzymały sklepienia krzyżowe, wspierające się na czterech filarach. Wówczas to średniowieczna wieża otrzymała zachowany do dziś, rozglifiony portal. W 1732 roku, w Heppenheim wybuchł pożar, podczas którego ucierpiał dach kościoła, który musiano odnowić, dobudowując doń sześć lukarn. W tym kształcie świątynia przetrwała do końca XIX wieku (rys. 14-15), chociaż już w 1 połowie XIX wieku rozważano jej przebudowę lub wzniesienie nowej. W roku 1884 ostatecznie zdecydowano się, że istniejący kościół jest zbyt mały i należy w jego miejscu wznieść nowy. W tym celu założono stowarzyszenie wspierające budowę kościoła oraz zatrudniono architekta - Ludwiga Beckera z Moguncji , aby rozpoczął pracę nad projektem. Plany budowy nowego kościoła były gotowe w 1886 roku. Według nich miał on być trzynawową bazyliką w stylu neogotyckim, z transeptem, kryptą i monumentalną wieżą zachodnią. Budowę świątyni rozpoczęto dopiero czternaście lat później - w 1900 roku. Wówczas także zmodyfikowano plany obiektu na życzenie ówczesnego starosty Heppenheim - barona von Grancy, który domagał się zachowania średniowiecz- 
nej wieży. Becker sprostał temu zadaniu, umiejętnie wpasowując ją w korpus nowego kościoła [1, 2,3].

Dokonując charakterystyki tego ważnego dla miasta obiektu należy zwrócić uwagę na położenie - na lekkim wzniesieniu, dzięki czemu jego bryła dominuje w sylwecie miasta. Kościół jest w dobrym stanie technicznym i do dzisiaj jest symbolem miasta, stanowiąc pozytywną dominantę architektoniczną na tle historycznej szachulcowej zabudowy centrum.

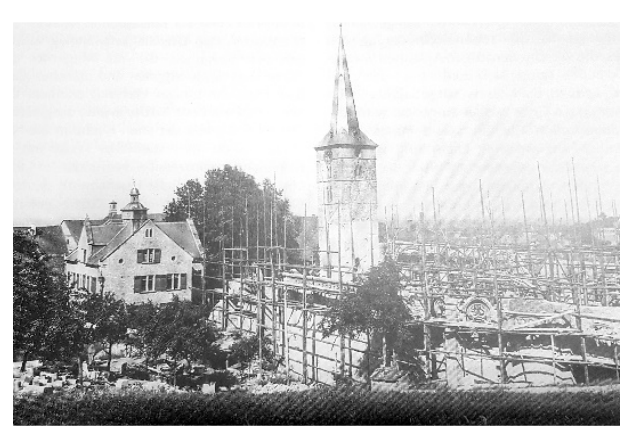

Rys. 12. Kościół pw. św. Piotra w Heppenheim na początku XX wieku, podczas przebudowy. Kopia zdjęcia [w:] Archiwum Autorów Fig. 12. St. Peter's church in Heppenheim at the beginning of the 20th century, during alterations. Copy of the photo [in:] the Authors' Archive

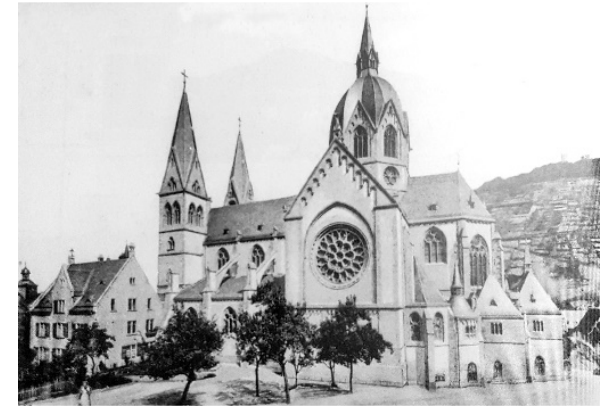

Rys. 13. Kościół pw. św. Piotra na początku $\mathrm{XX}$ wieku, po przebudowie. Kopia zdjęcia [w:] Archiwum Autorów

Fig. 13. St. Peter's church in Heppenheim at the beginning of the 20th century, after alterations. Copy of the phot [in:] the Authors' Archive

Opisując historię i krajobraz kulturowy Heppenheim nie można pominąć zamku Starkenburg położonego na wzniesieniu o kształcie stożka, górującym nad miastem. Warownia, o czym wspomniano już wcześniej, miała na celu obronę pobliskiego klasztoru w Lorsch. Pierwotnie Starkenburg nazywano „,burcheldon", co oznaczało górę, na której znajdowały się relikty prehistorycznych umocnień obronnych związanych zapewne z germańskim grodziskiem. Zamek powstał w roku 1065 i praktycznie od razu okazał się warownią nie do zdobycia, opierając się oblężeniu arcybiskupa Adalberta von Bremen. W ciągu następnych 700 lat został zdobyty tylko dwa razy: w roku 1631 przez Szwedów, a później w 1645 przez marszałka Turenne. W 1680 roku miała miejsce ostatnia rozbudowa twierdzy. Pod koniec wieku XVII ponownie, dwukrotnie próbowano zdobyć Starkenburg. Najpierw podczas wojny Francji z Ligą Augsburską: w 1689 roku oraz 4 lata później, w 1693 roku. W roku 1765 zezwolono na rozbiórkę zamku, ale wkrótce potem objęto go ochroną. Pomimo decyzji o ochronie twierdzy jej stan techniczny pogarszał się z roku na rok. W szczególnie złym stanie był stołp, który został wysadzony z powodu zagrożenia zawaleniem w 1924 roku. Rok później zaczęto rekonstruować jego formę, zmieniając przy tym nieznacznie 
lokalizację obiektu. Inwestycja ta trwała 25 lata i została zakończona uroczystym otwarciem w roku 1930. W roku 1955 przy dolnym dziedzińcu zamku, na miejscu dawnej winiarni z roku 1892, powstała mała gospoda. Pięć lat później odbudowano dawne palatium, lokalizując w nim schronisko młodzieżowe. W roku 1964 dobudowano doń wieżę strażniczą według sztychu Meriana, a w roku 1969 wieżę kuchenną po wschodniej stronie dolnego dziedzińca. W roku 1972 wzniesiono także wieżę armatnią przy północno-wschodnim narożniku murów zewnętrznych [4].

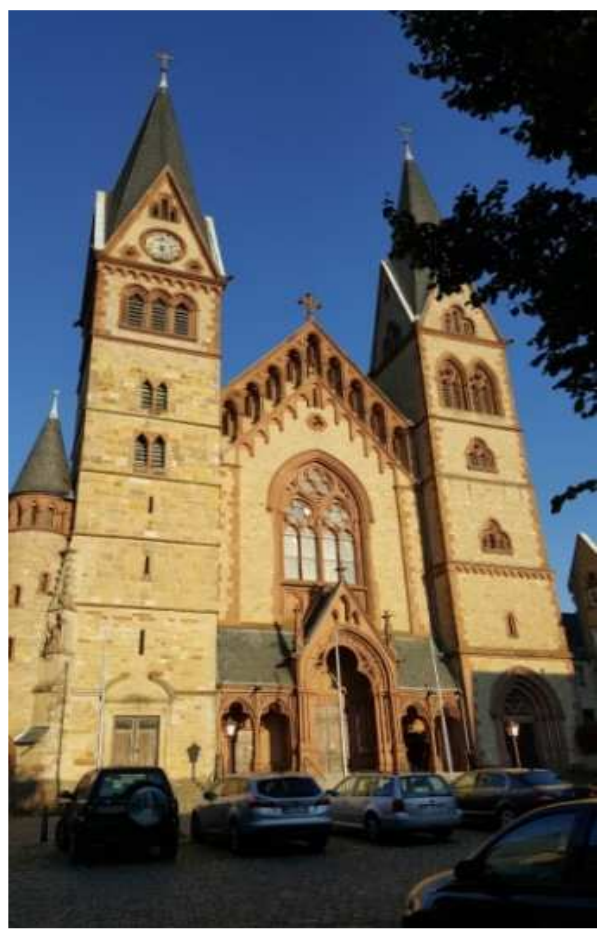

Rys. 14. Kościół pw. św. Piotra w Heppenheim obecnie. Widok na elewację frontową obiektu. Fot. Autorzy, 2016

Fig. 14. St. Peter's church in Heppenheim nowadays. View of the front elevation of the building. Photo: Authors, 2016

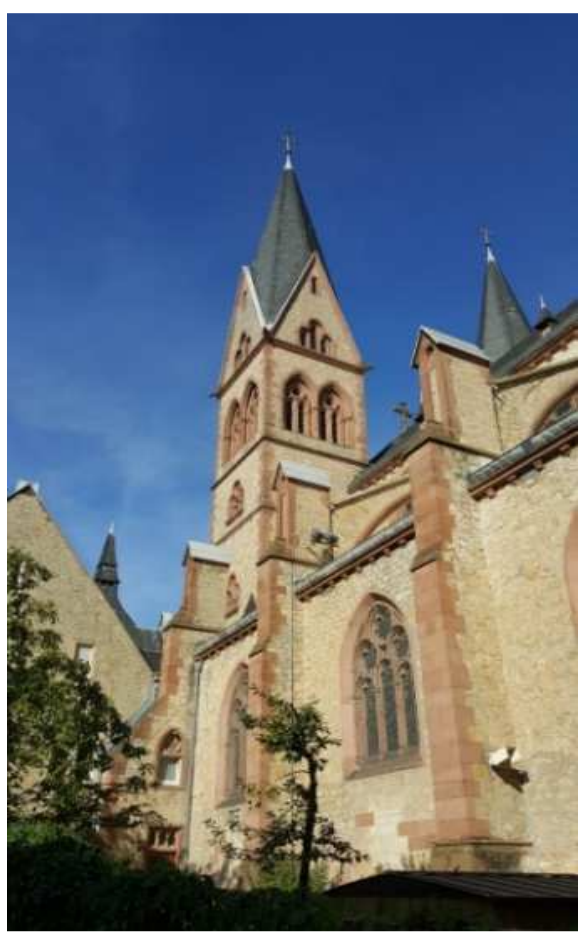

Rys. 15. Kościół pw. św. Piotra w Heppenheim obecnie. Widok na elewację boczną obiektu. Fot. Autorzy, 2016

Fig. 15. St. Peter's church in Heppenheim nowadays. View of the side elevation of the building. Photo: Authors, 2016

Obecnie Starkenburg, tak jak to miało miejsce przez ostatnie dziesięć stuleci, nadal stanowi symbol miasta Heppenheim, wiążąc jego historię z pobliskim klasztorem w Lorsch. Jest właściwie chroniony, a dzięki dobrze przeprowadzonemu procesowi rewaloryzacji jest jedną $\mathrm{z}$ piękniejszych twierdz $\mathrm{w}$ okolicy, stanowiąc także cenną atrakcję turystyczną jako zabytek oraz znane obserwatorium astronomiczne (rys. 16.). 


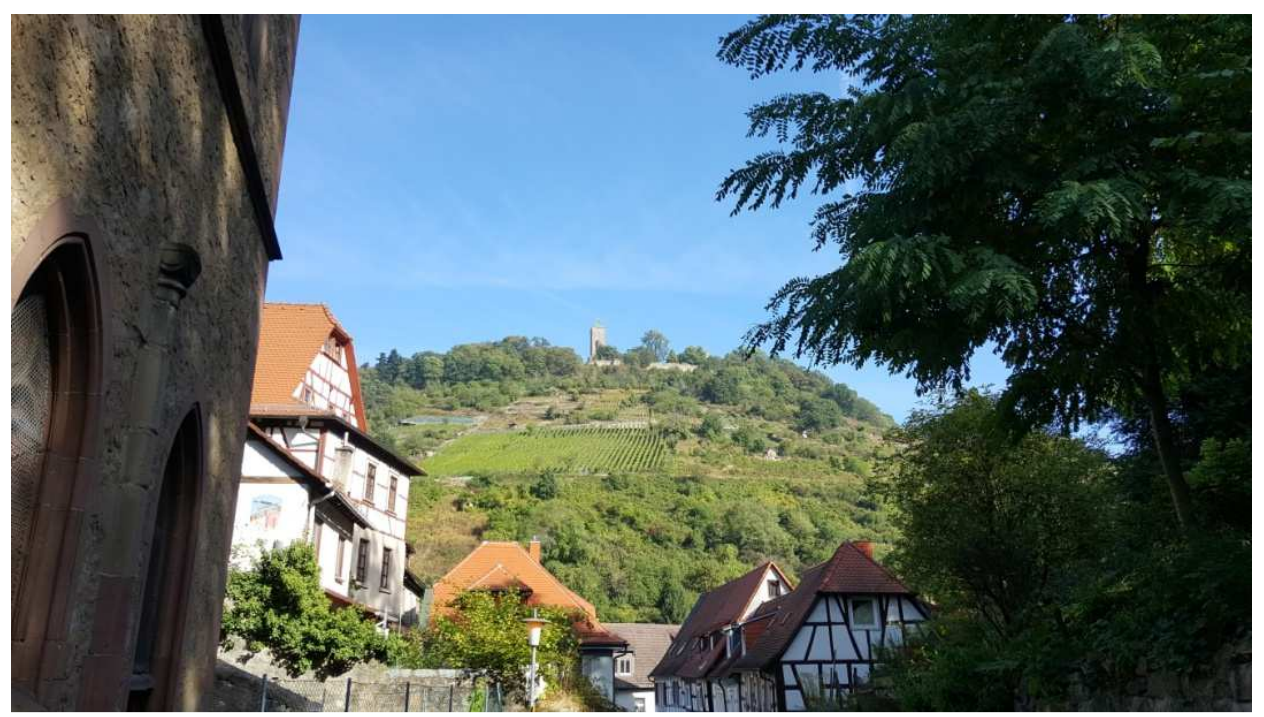

Rys.16. Widok na Starkenburg od strony kościoła pw. św. Piotra. Fot. Autorzy, 2016

Fig. 16. View of Starkenburg from the church of St. Peter. Photo: Authors, 2016

W południowej części starego miasta położony jest dawny Sąd Elektoratu Moguncji, wzniesiony w XIII wieku jako budynek (finalnie zespól budynków) administracyjny arcybiskupów Moguncji. Zlokalizowano go w sąsiedztwie średniowiecznych umocnień obronnych miasta. Zespół w rzucie ma kształt pięcioboku z wejściem do wewnętrznego dziedzińca od strony południowej. Najstarszą częścią zachowanego do dzisiaj obiektu jest fragment kamiennej budowli salowej, pochodzący z okresu jego powstania. Później, w wieku XIV, być może po pożarze jaki wybuchł w mieście w 1369 roku, została ona rozbudowana na wschód, obejmując dzisiejszą salę herbową. Z podobnego okresu pochodzi także wykusz chórowy zlokalizowany na wschodniej ścianie czworokątnej wieży, zajmującej część dziedzińca, a także położona w jej sąsiedztwie druga wieża, $\mathrm{z}$ wewnętrznymi kręconym schodami. Kolejnym budynkiem zespołu jest obiekt wzniesiony w konstrukcji szachulcowej, przylegający do muru obronnego. Prawdopodobnie pierwotnie znajdowała się tutaj hala, do której prowadziły trzy wejścia. Po wspomnianym wyżej pożarze w wieku XIV przebudowano tę część zespołu na pomieszczenie na prasę winiarską i dobudowano doń górną kondygnację w konstrukcji szachulcowej. Z kolei, na początku XVI wieku mieścił się tutaj wielki piec i łaźnia, a następnie do roku 1648 roku siedziba zarządcy finansów Heppenheim. Później w obiekcie miał swoją siedzibę burgrabia, pełniący funkcję zarządcy regionu. Budynek dawnego sądu Elektoratu Moguncji częściowo ucierpiał w pożarze miasta na końcu XVII wieku. Pomiędzy 1698 a 1710 rokiem został odbudowany z wyjątkiem części wschodniej i pozostał siedzibą zarządu regionu. Ruiny wspomnianego, nieodbudowanego fragmentu zespołu 
rozebrano dopiero w roku 1803 . W 1840 roku zespół został kupiony przez władze miasta, które wynajmowały jego pomieszczenia pod różne funkcje m.in. jako fabrykę cygar oraz szkołę podstawową.

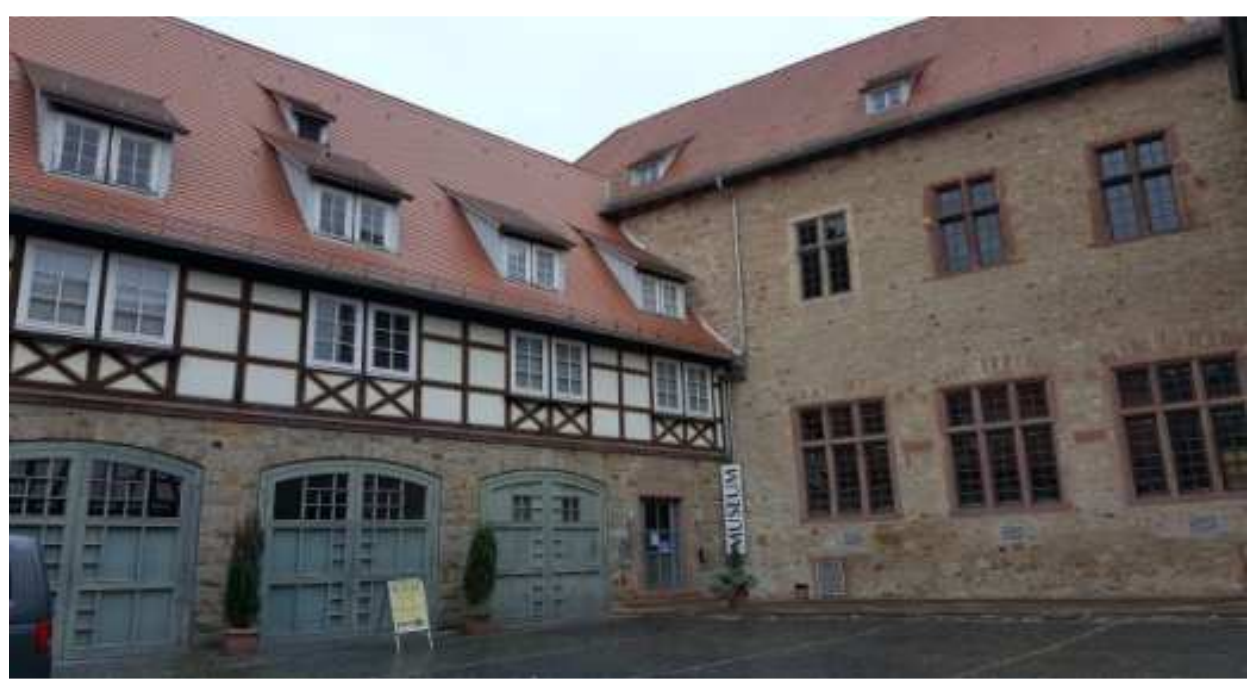

Rys. 17. Budynek Sądu Elektoratu Moguncji w Heppenheim obecnie. Widok na skrzydło zachodnie budynku. Fot. Autorzy, 2016

Fig. 17. Courthouse of the Mainz Electorate in Heppenheim nowadays. View of the west wing of the building. Photo: Authors, 2016

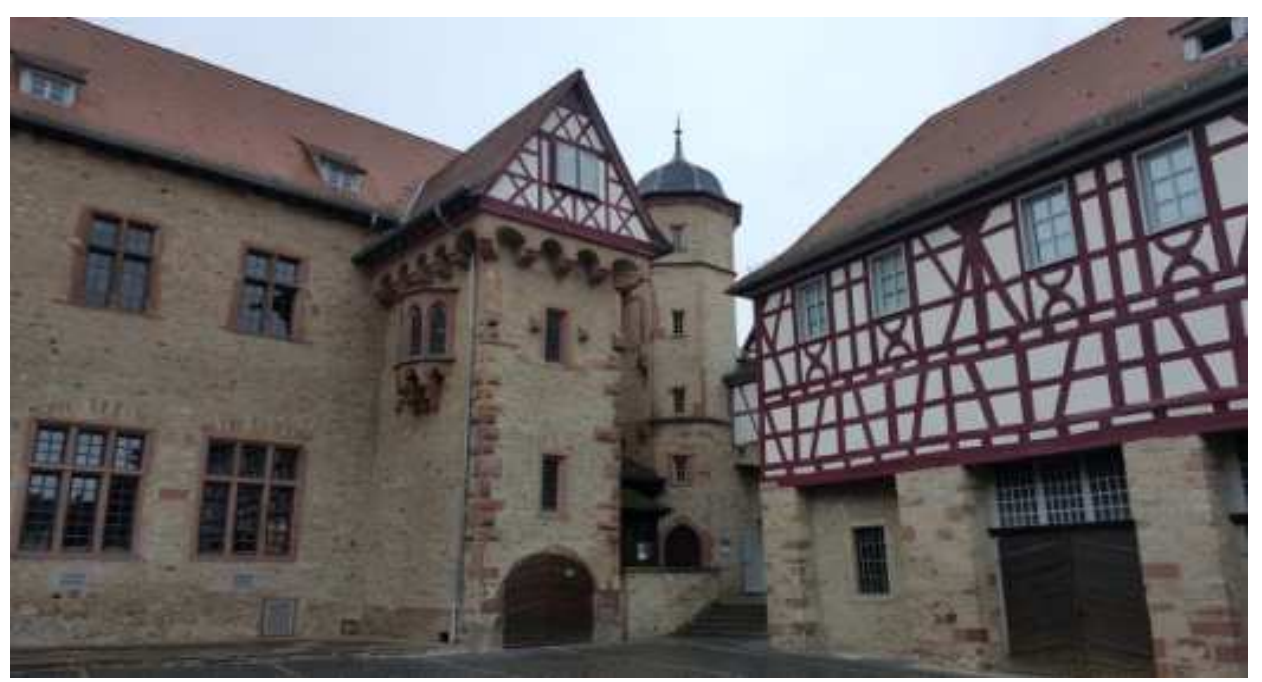

Rys. 18. Budynek Sądu Elektoratu Moguncji w Heppenheim obecnie. Widok na wykuszowe okno mieszczące kapliczkę oraz gotycką wieżę. Fot. Autorzy, 2016

Fig. 18. Courthouse of the Mainz Electorate in Heppenheim nowadays. View of the bay window housing the chapel, and the Gothic tower. Photo: Au-thors, 2016 


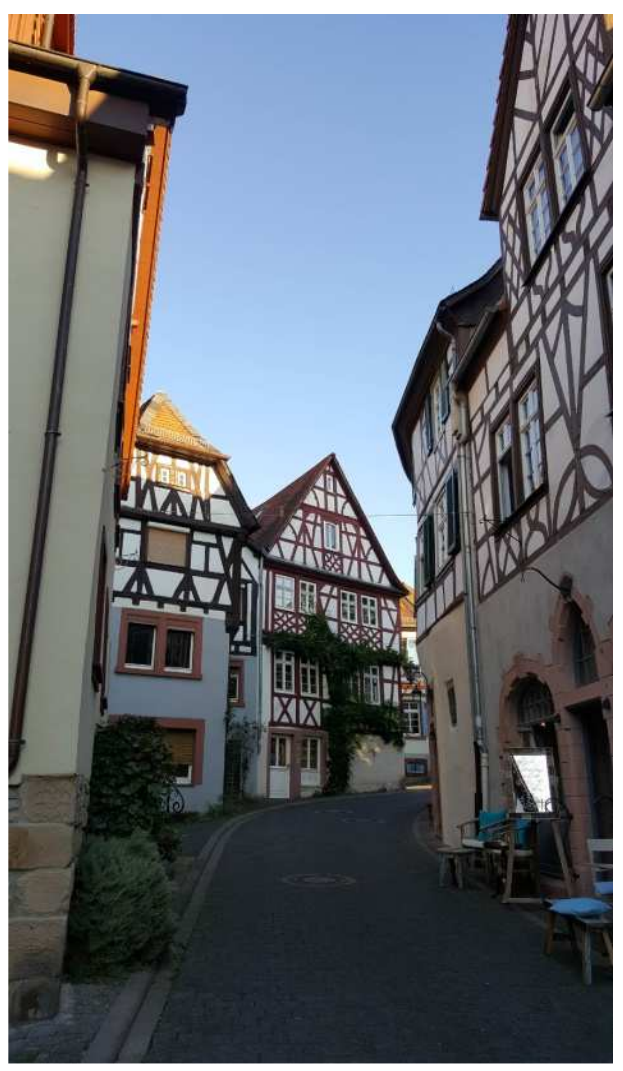

Rys. 19. Historyczna zabudowa przy Marktstrasse obecnie. Fot. Autorzy, 2016

Fig. 19. Historic buildings at Marktstrasse nowadays. Photo: Authors, 2016

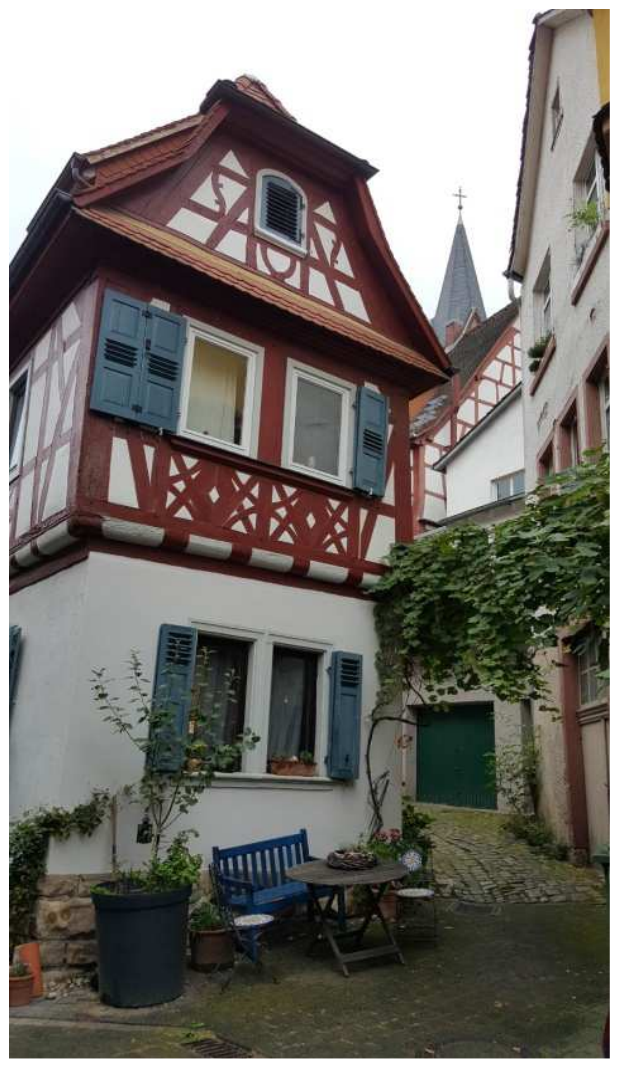

Rys. 20. Historyczna zabudowa przy Schunkengasse obecnie. Fot. Autorzy, 2016

Fig. 20. Historic buildings at Schunkengasse nowadays. Photo: Authors, 2016

Podsumowując lata 1800-1930 w historii dawnego sądu należy stwierdzić, że w okresie tym kompleks był zaniedbany. Brakowało również pomysłu na jego wykorzystanie. Wartość budowli docenił jako pierwszy w 1 połowie XX wieku Karl Schiffers, ówczesny burmistrz Heppenheim. Był on inicjatorem odnowy gmachu, który wymagał pilnego remontu. Było to jednak możliwe dopiero po 1930 roku, kiedy z zespołu wyprowadziła się wspomniana fabryka cygar. Wówczas dolną kondygnację głównego budynku ozdobiono ponowie malowidłami, a w sali elektorskiej przeprowadzono prace konserwatorskie. W roku 1955, z okazji 1200-ego jubileuszu miasta, odrestaurowano znajdującą się tam dekorację malarską z czasów Palatynatu i odnowiono salę herbową [10].

Obecnie dawny Sąd Elektoratu Moguncji jest siedzibą Muzeum Lokalnej Historii i Folkloru. Mieści się w nim również wschodnioniemieckie muzeum regionalne urządzone przez Związek Wypędzonych (rys. 17-18). 
Na terenie niemal całego starego miasta w Heppenheim zlokalizowana jest zabytkowa, historyczna zabudowa. Szczególnie cenne kulturowo domy położone są m.in. przy ulicy Kleine Bach, która swą nazwę przejęła od miejskiego potoku, wymienionego w źródłach już w 1480 r. Przy Kleine Bach, pod numerem 14, usytuowany jest najstarszy zachowany dom w Heppenheim, wzniesiony w konstrukcji szachulcowej.

Z kolei zabudowa wzdłuż Marktstrasse - ulicy prowadzącej z rynku w kierunku Bramy Wormackiej powstała między XVI a XVIII wiekiem (rys. 19-20). Najcenniejszym jej fragmentem są relikty tzw. Mönchsturm, średniowiecznej wieży mieszkalnej, pochodzącej z czasów kiedy miasto należało do opactwa z Lorsch.

Równie cenna kulturowo jest zabudowa mieszkalna położona przy Schunkengasse, która wychodzi z rynku w kierunku północno-wschodnim. Pochodzi ona przeważnie z XVII i XVIII wieku. W połowie ulicy zlokalizowane są kościelne schody z 1888 roku, która łączą ulicę z kościołem

\section{Krajobraz kulturowy Heppenheim, a turystyka kulturowa}

Pojęcie turystyki kulturowej w ostatnich latach przybrało na znaczeniu w m.in. kontekście pozyskiwania funduszy na ochronę dziedzictwa kulturowego. Według B. Marciszewskiej „Turystyka kulturowa stanowi aktywność osób w miejscu ich pobytu turystycznego [...], która pozwala na poznanie lub doświadczenie różnych sposobów życia innych ludzi - sposobów odzwierciedlających obyczaje społeczne, tradycje religijne, myśl intelektualną, dziedzictwo kulturowe i mających na celu zaspokojenie ludzkich potrzeb, pragnień oraz oczekiwań w zakresie kultury" [8]. Z kolei, co należy podkreślić, jak pisze J. Środulska-Wielgus ,związki kultury i turystyki są wielopłaszczyznowe: turystyka definiowana jako funkcja kultury, stała się jej elementem i płaszczyzną spotkania wielu kultury, a także katalizatorem przemian kulturowych" [11].

W tytule niniejszego artykułu wskazano Heppenheim jako wyjątkowy przykład właściwego wykorzystania dziedzictwa kulturowego miasta przez jego władze i społeczność lokalną na potrzeby turystyki kulturowej. Dzięki odnowionym zabytkom oraz innym atrakcjom takim jak m.in. wymienione wyżej Muzeum Lokalnej Historii i Folkloru; „Laternenweg” czy Amfiteatr, do miasta, będącego także jednym z punktów ,winnego" szlaku turystycznego, corocznie przybywają rzesze zwiedzających. Są to zarówno obcokrajowcy, jak i mieszkańcy okolicznych miast i wsi.

Wymienione wyżej „Laternenweg” (,Ścieżka latarni”) to zorganizowana w Heppenheim w 2004 roku trasa turystyczna. Uliczne latarnie ozdobiono ponad 150 ilustracjami w formie wycinanek, ilustrujących 150 motywów pochodzących ze świata legend Hesji. Stanowi to atrakcję także dla dzieci gdyż wycinanki obrazują historie o krasnoludkach, zaklętych rycerzach i legendarnych skarbach. Zarówno znane jak i niemal zapomniane opowieści ze wszystkich regionów 
Hesji zapraszają zwiedzających, w dzień i w nocy, do zagłębienia się w świat fascynujących mitów. Od maja do września, w każdy sobotni wieczór turyści mogą uczestniczyć w zwiedzaniu szlakiem „Laternenweg”, rozpoczynającym się przy rynku. Przechodząc obok podświetlonych wycinanek, mogą oni wysłuchać, z ust przebranych w średniowieczne stroje przewodników, opowiadań o tajemniczych, tragicznych, ale i komicznych wydarzeniach (rys. 21.).

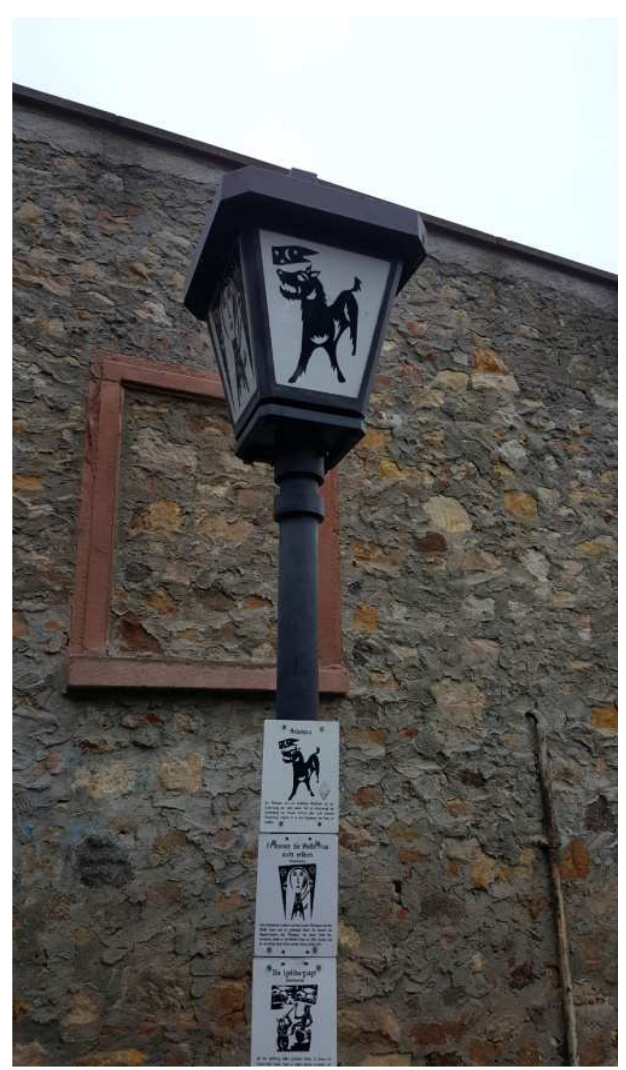

Rys. 21. Jedna z latarni na trasie turystycznej „Laternenweg”. Fot. Autorzy, 2016

Fig. 21. One of the lanterns along the "Lanternweg" tourist route. Photo: Authors, 2016

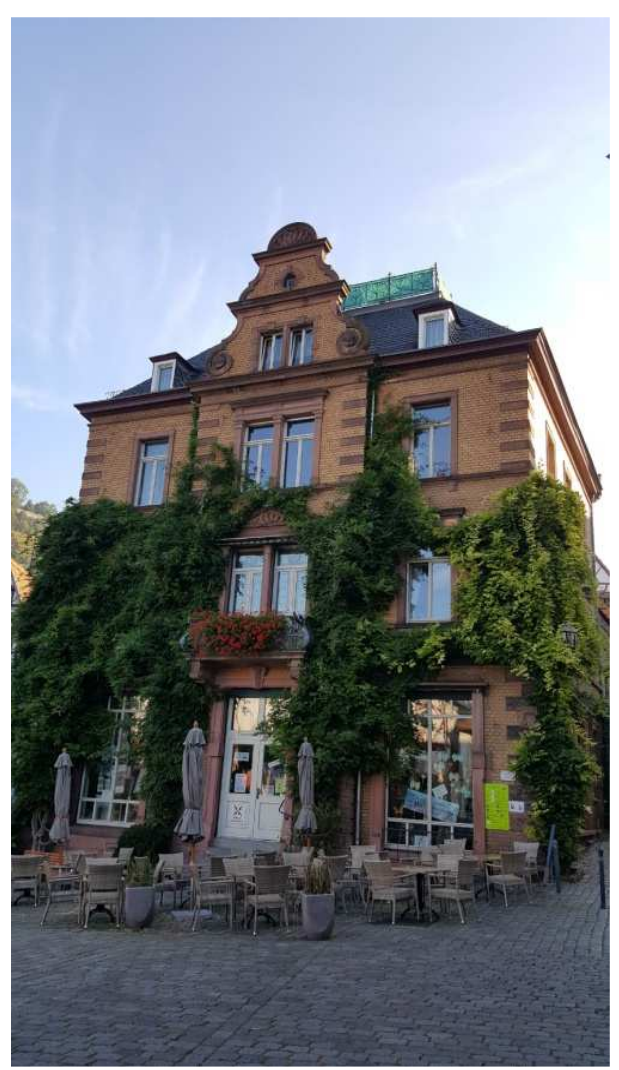

Rys. 22. Widok na punkt informacji turystycznej, zlokalizowany w rynku. Fot. Autorzy, 2016

Fig. 22. View of the tourist information point, located in the main square. Photo: Authors, 2016

Kolejnym elementem turystyki kulturowej miasta są liczne koncerty, przedstawienia teatralne oraz wieczory operowe, organizowane $\mathrm{w}$ amfiteatrze zbudowanym w 1955 roku dla uczczenia 1200 rocznicy powstania miasta. Półokrągła 
scena otoczona jest widownią, z której rozciąga się wspaniały widok na zamek Starkenburg.

Starkenburg oferuje natomiast, oprócz możliwości zwiedzania, także nocleg w schronisku młodzieżowym oraz regionalną kuchnię w zamkowej restauracji. Dodatkowo, zlokalizowane na zamku Obserwatorium Astronomiczne stanowi kanwę dla zorganizowanej w mieście trasy turystycznej „Droga Planet” („Planetenweg"), która prowadzi od Kleiner Markt przez miasto, aż na zamek. Turyści rozpoczynają zwiedzane od planety Pluton, którą można znaleźć przy domu jednego z założycieli obserwatorium, Alfreda Sturma, przy ulicy Kleine Bach 3, następnie wędrują przez winnice, aż do obserwatorium. Trasa przypomina spacer po układzie słonecznym, z proporcjonalnie odwzorowanymi odległościami. Turyści mijają wszystkie planety, podążając w ,towarzystwie” komet, aż do Słońca, które „znajduje się” w obserwatorium.

W podsumowaniu należy dodać, że w rynku, zaraz obok ratusza, w zabytkowym budynku, działa duży punkt informacji turystycznej, w którym można zasięgnąć informacji o historii miasta oraz jego ofercie turystycznej, a także kupić lokalne pamiątki (rys. 22.).

\section{Podsumowanie}

Opisany wyżej zasób kulturowy Heppenheim jest pokaźny, lecz nie wyjątkowy. Wyjątkowa, jest natomiast trafność, perfekcja oraz spójność jego rewaloryzacji oraz wykorzystania na potrzeby turystyki kulturowej. Ta konsekwencja w ochronie i popularyzacji wartości historycznych miasta doprowadziła do stworzenia ,produktu turystycznego”, działającego na bazie szeregu atrakcji funkcjonujących mieście, powiązanych z jego przeszłością i zasobem zabytkowym.

Przemyślana strategia, którą stosują władze Heppenheim - ochrony dziedzictwa $\mathrm{w}$ powiazaniu $\mathrm{z}$ jego odpowiednim wykorzystaniem na cele turystyki kulturowej wydaje się być cennym przykładem dla szeregu polskich, małych ośrodków zabytkowych, w tym tych położonych na Podkarpaciu. W wielu z nich, pomimo historycznej genezy powstania, pokaźnego zasobu zabytkowego brakuje wizji jak ów potencjał wykorzystać, aby przyczynił się do wieloaspektowego rozwoju miasta. Należy przy tym podkreślić fakt, że turystyka kulturowa oprócz wyżej wymienionych profitów dla miasta zabytkowego, niesie za sobą także wysoce pozytywny przekaz społeczny gdyż ,turystyka jest jednym z przejawów wysoko rozwiniętej kultury" [12], a także jak mówił papież Jan Paweł II „w dziedzictwie, jakim jest kultura, tkwi tożsamość narodu. Jest ona pierwszym i podstawowym nośnikiem - dowodem tożsamości narodu" [6]. 


\section{Literatura}

[1] 1200 Jahre Heppenheim. Im Gedenken an die erste urkundliche Erwahnung Heppenheims am 17. Juli 755, Herausgegeben vom Magistrat der Kreisstadt Heppenheirn an der Bergsrafśe, Heppenheim 1955.

[2] 900 Jahre Starkenburg. Veroffentlichungen zur Geschichte der Stadt Heppenheim, Herausgegeben vom Magistrat der Kreisstadt Heppenheim an der Bergstrafśe, Heppenheim 1965.

[3] 1250 Jahre Heppenheim, herausgegeben auf Anregung des Magistrats der Kreisstadt Heppenheim vom Verkehrs- und Heimatverein Heppenheim e.V. unter Mitwirkung des Geschichtsvereins Heppenheim und des Stadtarchivs Heppenheim, K. Härter, H. E. Jost, F. Kuhn (red.), Heppenheim 2005.

[4] Basler M., Grunewalder O., Vock I.: Starkenburg Castle, Wyd. District City Heppenheim, Heppenheim 2016.

[5] Heppenheim. Historical centre, M. Basler, U. Lange (red.), Wyd. Archive of district town Heppenheim, Heppenheim 2016.

[6] Jędrysiak T.: Turystyka kulturowa, Wyd. PWE, Warszawa 2008.

[7] Kuśnierz-Krupa D., Krupa M.: Lorsch - dziedzictwo Karolingów. Wstęp do badań nad dziedzictwem kulturowym miasta, „Wiadomości Konserwatorskie - Journal od Heritage Conservation", nr 50/2017, Wyd. ZG SKZ, Wrocław-Warszawa.

[8] Marciszewska B.: Społeczno-ekonomiczne uwarunkowania rozwoju turystyki kulturowej w Polsce, „Problemy turystyki i hotelarstwa”, nr 3, 2002.

[9] Metzendorf W.: Heppenheimer Lexikon - Ein ortskundliches Geschichtsbuch: Flurnamen, Gebäude, Strassen und Plätze, Wyd. Laurissa, Heppenheim 1994.

[10]Muller F.: Heppenheim Erleben, Wyd. Edition Diesbach, Weinheim 2007.

[11]Środulska-Wielgus J.: Rola turystyki kulturowej w ochronie i udostępnieniu krajobrazu warownego, Wyd. PK, Kraków 2016.

[12]Zaruski M.: Na bezdrożach tatrzańskich. Wycieczki, wrażenia i opisy, Wyd. Sport i turystyka, Warszawa 1958.

\section{HEPPENHEIM - A MODEL EXAMPLE OF WELL - USED CULTURAL POTENTIAL OF A SMALL TOWN}

\section{S u m m a r y}

Heppenheim is located in Hessen, in western Germany. It is a small town currently populated by 25 thousand inhabitants. However, the town can boast an eventful and colourful history, and valuable cultural resources which have been properly preserved, but primarily properly exhibited and used. Heppenheim was granted its town rights at the beginning of the 14th century, but it had been established much earlier. The first mention of its existence comes already from the 8th century. In the town there are e.g. a medieval, pentagonal main square with restored 17th-century timber-frame houses, a Baroque town hall, a parish church of St. Peter, the 12th-century Starkenburg castle, the building of the Mainz Electorate Courthouse from the 14th century and a myriad of 16th-, 17th- and 18th-century houses, characteristic for small-town German architecture, erected along narrow, picturesque streets of the historic town centre. Because of perfectly carried out 
revalorisation, accessibility and popularisation of historic objects and spaces among residents and visitors, Heppenheim can serve as a valuable model for other historic towns. Currently, many small towns in Poland, which can boast valuable cultural resources, face economic problems and lack of workplaces, which consequently leads to stagnation and lack of perspectives for further development. A way to make such towns progress economically and flourish can be cultural tourism so well developed in German towns, an example of which is Heppenheim.

Keywords: Heppenheim, cultural landscape, historic town, revalorisation

Przestano do redakcji: 09.06.2017 r.

Przyjęto do druku: 01.09.2017 r. 